\title{
PROGESTERONE VERSUS BETASYMPATHOMIMETIC SUPPLEMENTATION IN PRETERM LABOUR
}

\author{
By
Ahmad Fouad Goudah, Mohamed Samir Fouad and Mohamed Ibrahem Farahat \\ Department of Obstetrics and Gynecology, Faculty of Medicine, Al-Azhar University \\ Corresponding author: Ahmad Fouad Goudah,
}

Mobile: (+20) 01007100238, E-mail: a.fouad.dr@gmail.com

\begin{abstract}
Background: The significance of premature birth cannot be underestimated. Being born too early is the major cause of perinatal morbidity and mortality accounting for 85 percent of all early infant deaths, not secondary to congenital abnormality.

Objective: To compare between the efficacy of progesterone and ritodrine (beta-sympathomimetic) in the management of threatened preterm labour.

Patients and methods: In the present study we aimed to compare between the efficacy of progesterone and Ritodrine (beta-sympathomimetic) in the management of threatened preterm labor on 100 females presenting with preterm labour, randomized into two groups using simple randomization, where 50 patients received Ritodrine and 50 patients received progesterone.

Results: The success rate of the drugs to delay delivery more than $48 \mathrm{~h}$ there was $72 \%$ in Ritodrine group and $38 \%$ in progesterone group with a statistically significant difference between the two study groups. There was a statistically significant difference in neonatal weight at delivery and neonatal intensive care unit (NICU) admission between the two study groups, which may be related to gestational age at delivery that has shown significant difference between the two study groups.

Conclusion: The success rate of Ritodrine to prevent preterm delivery was better than Progesterone, but the side effects were more serious. Therefore, we recommend starting tocolysis with Ritodrine within the first 48 hours, then to continue with progesterone to avoid the undesirable side effects of Ritodrine.
\end{abstract}

Keywords: Progesterone, Betasympathomimetic, Preterm Labour.

\section{INTRODUCTION}

Advances in perinatology and neonatology in the past decade have resulted in increased survival rates, particularly for the extremely premature baby (born between 24 and 27 weeks' gestation) but unfortunately the associated morbidity for these survivors remains significant where one-fifth to one-quarter will suffer at least one major disability including chronic lung disease, impaired mental development, cerebral palsy, deafness, or blindness (Georgiou et al., 2015). Even late preterm infants (born between 32 and 36 weeks' gestation) have a greater risk of respiratory distress syndrome, feeding difficulties, temperature instability, jaundice, and delayed brain development (Kugelman and Colin, 2013). 
Progesterone is a steroid hormone initially produced by the corpus luteum. In early pregnancy, progesterone is critical for pregnancy maintenance until the placenta takes over this function at 7 to 9 weeks of gestation, and its name is derived from this function: pro-gestational steroidal ketone. Indeed, removal of the source of progesterone (the corpus luteum) (Dante et al., 2013) or administration of a progesterone receptor antagonist (Norman and Bennett, 2017) readily induces abortion before 7 weeks (49 days) of gestation.

Progesterone appears to be important in maintaining uterine quiescence in the latter half of pregnancy; however, the mechanism is unclear. Functional withdrawal of progesterone activity at the level of the uterus appears to occur proximate to the onset of labor both at term and preterm, without a significant change in serum progesterone levels in the weeks preceding labor. Progesterone also prevents apoptosis in fetal membrane explants under both basal and proinflammatory conditions and thus may protect the membranes from preterm premature rupture and, in turn, preterm birth (Norwitz et al., 2019).

Ritodrine, a beta-2-adrenergic agonist, relaxes the uterus by stimulating the beta2-adrenergic receptors of the uterine muscle, which causes a decrease in the intensity and frequency of uterine contractions. Specifically, ritodrine decreases uterine myometrial contractility by increasing cellular cyclic adenosine monophosphate (cAMP) and increasing cell membrane cytokines that increase and sequester intracellular calcium. Without intracellular calcium, the activation of contractile protein of smooth muscle is prevented and the uterus relaxes (Kumari, 2019).

The aim of this study is to compare between the efficacy of progesterone and ritodrine (beta-sympathomimetic) in the management of threatened preterm labour.

\section{PATIENTS AND METHODS}

We performed a prospective randomized study on 100 females presenting with preterm labor to the Department of Obstetrics and Gynaecology, EL-Galaa Teaching Hospital, between March 2017 and November 2018, randomized into two groups using simple randomization, where one group received ritodrine and the other group received progesterone, with the following criteria:

\section{Inclusion criteria:}

Gestational age of 24 up to $36+6$ weeks. Singleton pregnancy. Cephalic presentation. Uterine contractions four in $20 \mathrm{~min}$ or eight in $60 \mathrm{~min}$ lasting for 30 seconds or more. Cervical dilation 1 to 3 $\mathrm{cm}$. Cervical effacement $50 \%$ or greater. And intact membranes.

\section{Exclusion criteria:}

Gestational hypertension, preeclampsia, eclampsia \&chronic hypertension. Chronic diseases such as history of cardiac disease, renal disease. And urinary tract infection.

Complete history was taken regarding age, occupation, Socio-economic status, and any history of infections, obstetric history, and history of previous preterm deliveries, abortions, history of diabetes mellitus, heart disease, chronic renal failure, hypertension and asthma. Period 
of gestation was calculated with known last menstrual period and assessed by clinical examination and ultrasound. Patient's general physical examination was done. Vital signs were recorded. Cardiovascular system and respiratory system were examined. Abdominal examination for uterine heights, presentation, position, lie of the fetus, liquor volume as well as fetal heart rate were recorded. Uterine contractions were evaluated with respect to frequency and duration.

Group 1: Fifty patients were received beta ritodrine $10 \mathrm{mg}$ initially infused intravenously along with 5\% dextrose at the rate of 10 drops (10 microgram) per minute with an increase of 5-10 drops every 30 minutes up to 100 microgram per min for 24 hours and then given oral at 5-10 mg eight hourly.

Group 2: 50 patients were received 400mg vaginal progesterone daily till maturity.

\section{Diagnosis of preterm labor:}

Clinical criteria: Regular painful uterine contraction: 4every 20 minutes or 8 every 60 minutes. Documented cervical change: cervical effacement of at least $8 \%$ or dilatation $>2 \mathrm{~cm}$.

Investigations: help to support or exclude the diagnosis: US measurement of cervical length: short cervix $(<30 \mathrm{~mm})$ is predictive of an increased risk of preterm labour and birth; the shorter the cervix, the higher the risk of preterm birth.

Full investigation for mother was done (CBC-FBS-urine analysis-liver and kidney function test).

\begin{abstract}
All patients received intramascular corticosteroid for premature fetal lung prophylaxis: (A) Betamethazone: two doses of $12 \mathrm{mg} 24$ hours apart. (B) Dexamethazone: four doses of $6 \mathrm{mg} 12$ hours apart.
\end{abstract}

Determination of the baseline mean arterial blood pressure, maternal heart rate, pelvic examination and fetal heart rate assessment were done before the start of the treatment Clinical follow up was done by measuring frequency of uterine contractions and Bishop score 6 hours after the start treatment, mean maternal blood pressure, maternal heart rate and the occurrence of maternal side effects during tocolysis. The response to treatment was assessed by the time after which cessation of pains and cervical changes occurred, prolongation of gestation, duration after which cases were delivered or shifted to other tocolytic therapy.

Treatment continued for 24 hours. Maintenance therapy till 37 weeks of gestation in the form of: $5-10 \mathrm{mg}$ Ritodrine tablet every 8hours for group 1 and 400mg progesterone suppositories daily for group 2. After delivery, the neonate was evaluated for birth weight, congenital anomalies, Apgar score at 1 and 5 minutes. The babies were shifted to NICU if needed.

\section{Data analysis:}

The data were collected, coded, revised, verified, and computerized. Statistical analyses were done using SPSS statistical package version 16. (IBM Corp, Chicago, IL, USA) Qualitative data were presented in the form of numbers and percentages and quantitative variables as mean and standard deviation (SD). A comparison between quantitative variables 
was carried out by the student t-test of two independent samples. Chi-square test $\left(\mathrm{X}^{2}\right)$, was used to compare qualitative variables.

\section{RESULTS}

In group 1, the mean age was $28.68 \pm 6.20$, whereas in group 2 , the mean age was $29.44 \pm 5.72$. There was no significant difference $(\mathrm{p}=0.525)$ in the mean age distribution between the 2 groups (Table 1).

Table (1): Age distribution among study groups

\begin{tabular}{|c|c|c|c|}
\hline \multirow{2}{*}{ Age (ys) } & Ritodrin group & Progesterone group & \multirow{2}{*}{ P-value } \\
\cline { 2 - 3 } & No. $=\mathbf{5 0}$ & No. $=\mathbf{5 0}$ & \multirow{2}{*}{0.525} \\
\hline Mean \pm SD & $28.68 \pm 6.20$ & $29.44 \pm 5.72$ \\
Range & $19-38$ & $19-38$ & \\
\hline
\end{tabular}

$\bullet$ Independent t-test

There was no significant difference in the parity, number of previous preterm labours or number of abortions between the two groups (Table 2).

Table (2): Comparison between Ritodrin group and Progesterone group regarding parity, previous preterm labours and abortion

\begin{tabular}{|c|c|c|c|c|c|c|}
\hline \multirow{2}{*}{ Parameters } & Groups & \multicolumn{2}{c|}{ Ritodrin group } & \multicolumn{2}{c|}{ Progesterone group } & \multirow{2}{*}{ P-value } \\
\cline { 3 - 6 } & & No. & $\%$ & No. & $\%$ & \\
\hline \multirow{3}{*}{ Parity } & 0 & 5 & $10.0 \%$ & 0 & $0.0 \%$ & \\
& 1 & 17 & $34.0 \%$ & 15 & $30.0 \%$ & \\
& 2 & 13 & $26.0 \%$ & 19 & $38.0 \%$ & $>0.05$ \\
& 3 & 10 & $20.0 \%$ & 12 & $24.0 \%$ & \\
& More than 3 & 5 & $10.0 \%$ & 4 & $8.0 \%$ & \\
\hline \multirow{3}{*}{ Previous Preterm } & 0 & 25 & $50.0 \%$ & 25 & $50.0 \%$ & \\
labours & 1 & 13 & $26.0 \%$ & 12 & $24.0 \%$ & $>0.05$ \\
& 2 & 10 & $20.0 \%$ & 11 & $22.0 \%$ & \\
\hline \multirow{3}{*}{ Abortion } & 3 & 2 & $4.0 \%$ & 2 & $4.0 \%$ & \\
& 0 & 15 & $30.0 \%$ & 15 & $30.0 \%$ & \\
& 1 & 14 & $28.0 \%$ & 16 & $32.0 \%$ & $>0.05$ \\
& 2 & 18 & $36.0 \%$ & 17 & $34.0 \%$ & \\
& 3 & 3 & $6.0 \%$ & 2 & $4.0 \%$ & \\
\hline
\end{tabular}

*:Chi-square test

There was a highly statistically significant difference $(\mathrm{p}=0.001)$ in number of delivery before 48 hours between the two groups. In first group (Ritodrin), 14 cases (28\%), whereas in second group (progesterone) 31 cases $(62 \%)$ delivered before 48 hours which was $45 \%$ of all cases. Also, there is a highly statistically significant difference $(\mathrm{p}=0.003)$ in reaching maturity between the two groups. In first group (Ritodrin) 20 cases $(40 \%)$, whereas in second group (progesterone) only 7 cases $(14 \%)$ delayed delivery till reaching maturity which is 
$27 \%$ of all cases. On the other hand, there is no significant difference $(\mathrm{p}=0.373)$ in number of women in which the delivery was delayed for more than 48 hours but less than 37 weeks. In first group

Table (3): Effect of the two drugs on prevention of preterm labour

\begin{tabular}{|l|l|c|c|c|c|c|}
\hline \multirow{2}{*}{ Parameters } & Groups & \multicolumn{2}{|c|}{ Ritodrin group } & \multicolumn{2}{c|}{ Progesterone group } & \multirow{2}{*}{ P-value } \\
\cline { 3 - 7 } & & No. & $\%$ & No. & $\%$ & \\
\hline Failed to delay delivery & Negative & 36 & $72.0 \%$ & 19 & $38.0 \%$ & \multirow{2}{*}{0.001} \\
more than 48h & Positive & 14 & $28.0 \%$ & 31 & $62.0 \%$ & \\
\hline Delay delivery $>$ & Negative & 34 & $68.0 \%$ & 38 & $76.0 \%$ & \multirow{2}{*}{0.373} \\
48\&before maturity & Positive & 16 & $32.0 \%$ & 12 & $24.0 \%$ & \\
\hline \multirow{2}{*}{ Reaching maturity } & Negative & 30 & $60.0 \%$ & 43 & $86.0 \%$ & \multirow{2}{*}{0.003} \\
\hline
\end{tabular}

*:Chi-square test

There was a highly statistically significant difference $(\mathrm{p}=0.005)$ in Neonatal weight at delivery between the two groups, Also, There was a highly statistically significant difference (p $=0.008)$ in NICU admission between the two groups. In group 1 , the mean of gestational age at delivery was $35.14 \pm$ 3.37 , whereas in group 2 , the mean of gestational age at delivery was
(Ritodrin), 16 cases (32\%), whereas in second group (progesterone) 12 cases (24\%) delayed delivery more than 48 hours which is $28 \%$ of all cases (Table 3 ).

Table (4): Comparison between Ritodrin group \& Progesterone group regarding time of contraction (week), gestational age at delivery, neonatal weight at delivery and NICU

\begin{tabular}{|c|c|c|c|c|}
\hline \multirow{2}{*}{\multicolumn{2}{|c|}{$\begin{array}{ll}\text { Parameters } & \text { Groups } \\
\end{array}$}} & Ritodrin group & Progesterone group & \multirow{2}{*}{ P-value } \\
\hline & & \multirow{2}{*}{$\begin{array}{c}\text { No. }=\mathbf{5 0} \\
31.46 \pm 1.36 \\
29-34 \\
\end{array}$} & \multirow{2}{*}{$\begin{array}{c}\text { No. }=\mathbf{5 0} \\
31.46 \pm 1.36 \\
29-34 \\
\end{array}$} & \\
\hline $\begin{array}{l}\text { Time of contraction } \\
\text { (weeks) }\end{array}$ & \begin{tabular}{|l} 
Mean \pm SD \\
Range
\end{tabular} & & & 1.000 \\
\hline $\begin{array}{l}\text { Gestational age } \\
\text { at delivery }\end{array}$ & \begin{tabular}{|l|} 
Mean \pm SD \\
Range
\end{tabular} & $\begin{array}{c}35.14 \pm 3.37 \\
29-39 \\
\end{array}$ & $\begin{array}{c}33.45 \pm 3.13 \\
29-38.4 \\
\end{array}$ & 0.011 \\
\hline $\begin{array}{l}\text { Neonatal weight } \\
\text { at delivery }\end{array}$ & $\begin{array}{l}\text { Mean } \pm \text { SD } \\
\text { Range }\end{array}$ & $\begin{array}{c}2569.00 \pm 799.16 \\
1000-3700\end{array}$ & $\begin{array}{c}2014.00 \pm 1103.80 \\
900-3700\end{array}$ & 0.005 \\
\hline APGR 1 & $\begin{array}{l}\text { Mean } \pm \text { SD } \\
\text { Range }\end{array}$ & $\begin{array}{c}7.20 \pm 0.97 \\
5-9\end{array}$ & $\begin{array}{c}6.86 \pm 1.16 \\
5-9\end{array}$ & 0.115 \\
\hline APGR 5 & $\begin{array}{l}\text { Mean } \pm \text { SD } \\
\text { Range } \\
\end{array}$ & $\begin{array}{c}8.62 \pm 0.95 \\
6-10\end{array}$ & $\begin{array}{c}8.22 \pm 1.25 \\
6-10\end{array}$ & 0.074 \\
\hline $\begin{array}{l}\text { NICU } \\
\text { Neonatal intensive } \\
\text { care unit }\end{array}$ & $\begin{array}{l}\text { Negative } \\
\text { Positive }\end{array}$ & $\begin{array}{l}42(84.0 \%) \\
8(16.0 \%)\end{array}$ & $\begin{array}{l}30(60.0 \%) \\
20(40.0 \%)\end{array}$ & 0.008 \\
\hline
\end{tabular}

*:Chi-square test; $\bullet:$ Independent t-test 


\section{DISCUSSION}

When comparing patient characteristics in the two study groups, there was no statistically significant difference between study groups as regards the age, parity, gestational age at admission and number of previous preterm labor and abortions. Also, there were no statisticaly significant difference in cervical dilation and cervical effacement in between patients included in the study groups. The success rate of the drugs to delay delivery more than $48 \mathrm{~h}$ was $(72 \%)$ in Ritodrine group and $(38 \%)$ in Progesterone group with a highly statistically significant difference between the two study groups. Neonates had a birth weight $(2569.00 \pm 799.16)$ in Ritodrine group and (2014.00 \pm 1103.80) in progesterone group.

Also, the percentage of women reaching maturity was $40 \%$ in Ritodrine group and the mean gestational age was $(35.14 \pm 3.37 \mathrm{w})$ at delivery, and the percentage of women reaching maturity was only $14 \%$ in progesterone group with mean gestational age $(33.45 \pm 3.13 \mathrm{w})$ at delivery. The percentage of women in which the delivery Delayed more than $48 \mathrm{~h}$ and delivered before reaching maturity was also higher in ritodrine group $(32 \%)$ than in progesterone group $(24 \%)$, but with no significant difference between two groups.

In our study, there was a significant difference in neonatal weight at delivery and NICU admission between the two study groups, which may be related to gestational age at delivery that has shown significant difference between the two study groups.

Shahzad et al. (2015) showed that there were $31.7 \%$ of patients in whom the prolongation of labor for 48 hours was observed in Ritodrine Group, while in $68.3 \%$ patients; no prolongation of labor was seen.

Driul et al. (2014) showed that ritodrine was effective to delay delivery more than $48 \mathrm{~h}$ in $81.73 \%$. The results are close to our results where Ritodrine was effective to delay preterm labor.

Regarding progesterone, our results were not in agreement with Freak-Poli et al. (2009) in which $200 \mathrm{mg}$ daily vaginal progesterone was used in pregnant women from 24 to 34 weeks of gestations and reported that incidence of delivery before 34 weeks of gestation was only $19.2 \%$ with progesterone, while in our results, 62 $\%$ failed to delay delivery for more than 48 hours regardless the gestational age.

Likewise, in contrary to our result, Alavi et al. (2016) showed vaginal progesterone suppository (200 $\mathrm{mg}$ ) can probably help to prevent preterm labour and such complications as respiratory problems or the need for artificial ventilation. Alavi et al. (2016) reported that $80 \%$ of mothers reaching maturity compared to $14 \%$ in our results, and Birth weight in $80 \%$ of infants $>2500 \mathrm{~g}$. Only $9 \%$ of the infants had respiratory problems which needed hospitalization and artificial ventilation compared to $40 \%$ of infants admitted to NICU in our study.

Our results were in agreement with the results reported by Choi (2017) that progesterone did not decrease the frequency of preterm birth rates.

\section{CONCLUSION}

Ritodrine was more successful in delaying the delivery and reaching maturity than progesterone, especially for 
first 48 hours which was nearly double that in progesterone. The mean prolongation of gestation was higher for Ritodrine when compared to Progesterone. Ritodrine can beuled for the first 48 hours in acute pretem labour then continue with progesterone after that.

\section{REFERENCES}

1. Alavi A, Hamadiyan $H$ and Darijani $M$. (2016): Effect of vaginal progesterone suppository $(200 \mathrm{mg})$ on preventing preterm labor after the inhibition of uterine contractions: A randomized clinical trial. Int J Med Res Health Sci., 5(10):21-66.

2. Choi SJ. (2017): Use of progesterone supplement therapy for prevention of preterm birth: review of literatures. Obstet Gynecol Sci., 60(5): 405-420.

3. Dante G, Vaccaro $V$ and Facchinetti $F$. (2013): Use of progestagens during early pregnancy. Facts Views Vis Obgyn., 5 (1): 66-71.

4. Driul L, Londero AP, Adorati-Menegato A, Vogrig E, Bertozzi S, Fachechi G, Forzano L, Cacciaguerra G, Perin E, Miceli A and Marchesoni D. (2014): Therapy side-effects and predictive factors for preterm delivery in patients undergoing tocolysis with atosiban or ritodrine for threatened preterm labour. Journal of Obstetrics and Gynaecology, 34(8):684-689.

5. Freak-Poli $R$, Chan A, Tucker $G$ and Street J. (2009): Previous abortion and risk of pre-term birth: a population study. The
Journal of Maternal-Fetal \& Neonatal Medicine, 22(1):1-7.

6. Georgiou HM, Di Quinzio MK, Permezel $M$ and Brennecke S. (2015): Predicting Preterm Labour: Current Status and Future Prospects. Dis Markers, 15: 435014.

7. Kugelman A and Colin AA. (2013): Late preterm infants: near term but still in a critical developmental time period. Pediatrics, 132(4): 741-751.

8. Kumari U. (2019): Textbook of Obstetrics: preterm labour - E - Book Kindle Edition. Churchill Livingstone (London, England); Part V, Pp. 201.

9. Norman JE and Bennett P. (2017): Preterm birth prevention-Time to progress beyond progesterone. PLoS Med., 14:e1002391.

10. Roy V, Prasad GS and Latha K. (2006): Tocolysis with ritodrine: a comparative study in preterm labour. Pakistan Journal of Medical Sciences, 22 (1): 64-69.

11. Shahzad N, Saleem F, Shahid $M$ and Malik A. (2015): Comparison between nifedipine and ritodrine as an effective tocolytic agent for preterm labour. Annals of King Edward Medical University, 21(2):113116.

12. Yaju $Y$ and Takeo N. (2006): Effectiveness and Safety of Ritodrine Hydrochloride for the Treatment of Preterm Labour: A Systematic Review. Pharmacoepidemiology and Drug Safety, 15(11): 813-822. 


\section{AHMAD FOUAD GOUDAH et al.,}

\section{مقارنة بين استخدام البروجسترون والريتودرين في حالات الولادة المبكرة}

أحمد فؤاد جودة، محمد سمير فؤاد، محمد إبراهيم فرحات

قسم التوليد وأمراض النساء، كلية الطب، جامعة الأزهر

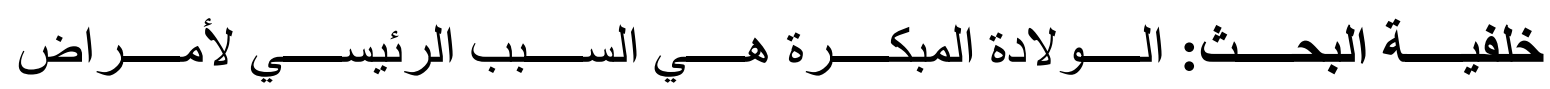

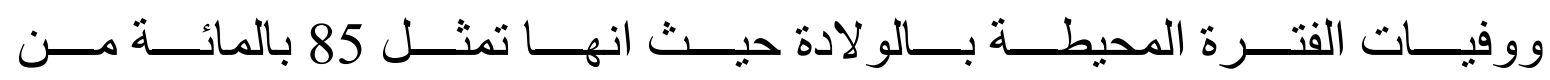

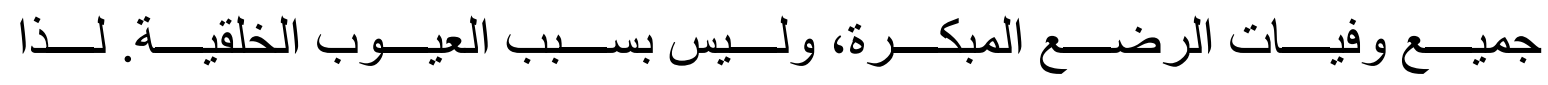

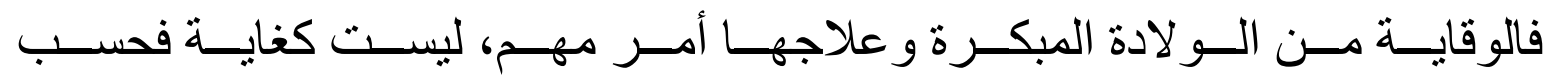

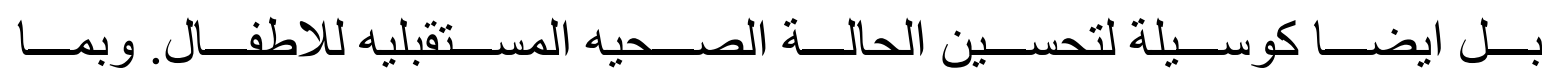

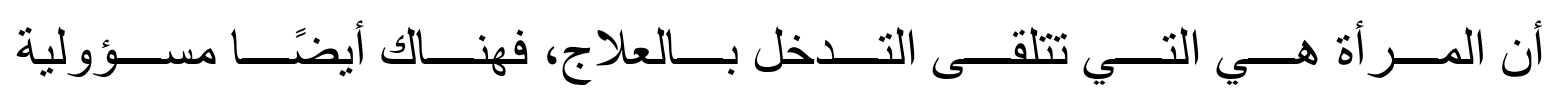
بضمان عدم تعرضها لأي ضرر.

الهـــف مــن البحــث: فــي در اســتنا نحـن نهـدف إلــى المقارنــة بــين فعاليــة هرمون البروجسترون وبين الريتودرين في علاج الو لاده المبكره.

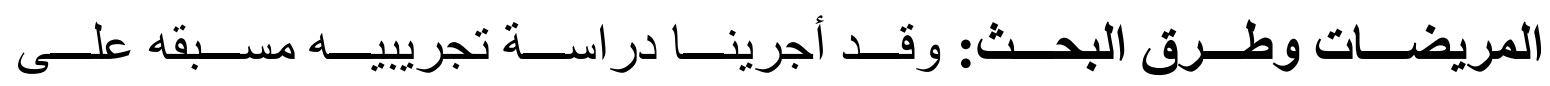

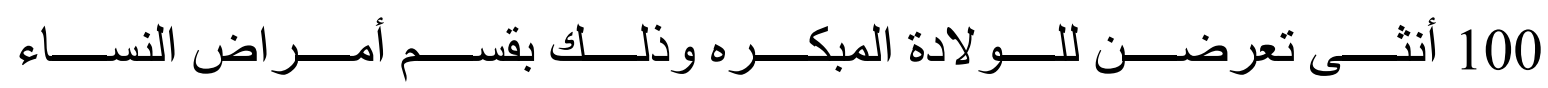

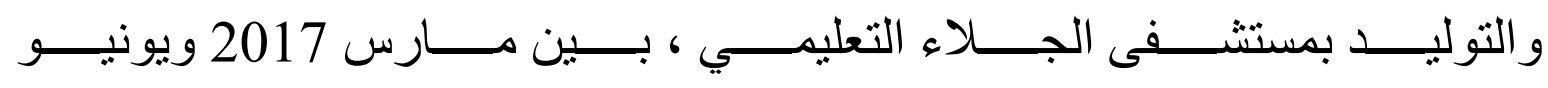

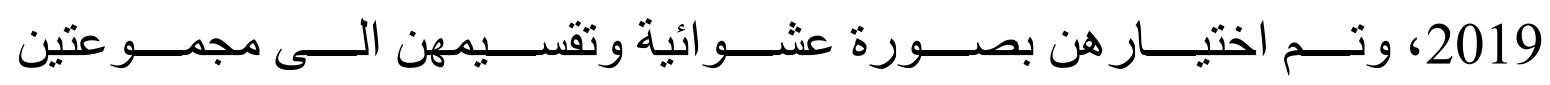

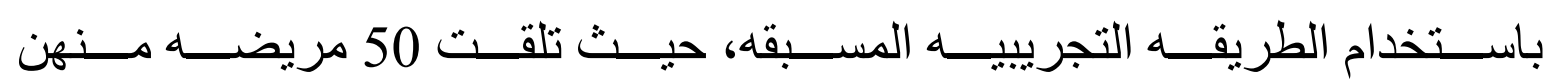
الريتودرين و50 مريضه تلقين هرمون البروجسترون.

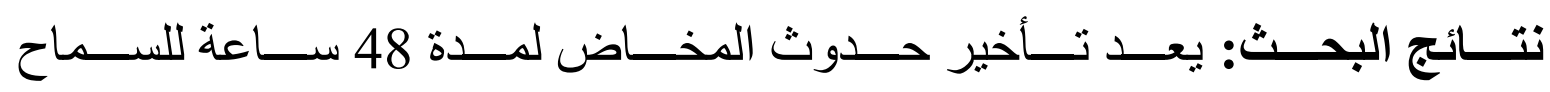

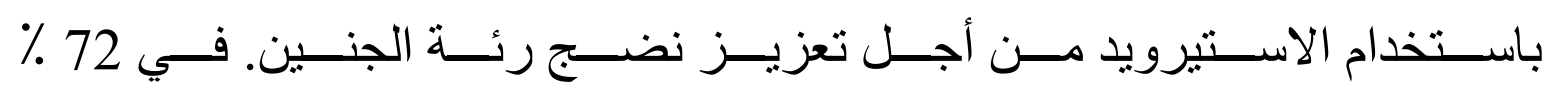

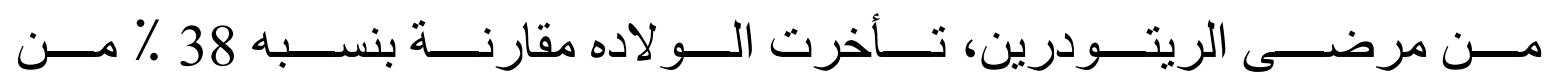




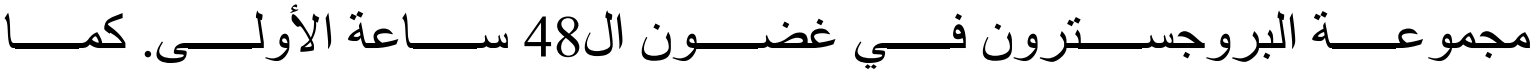

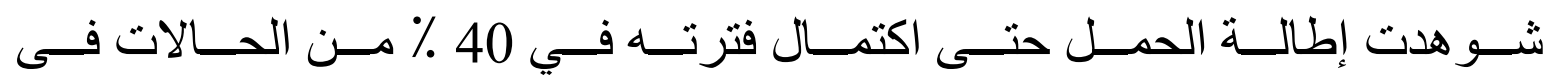

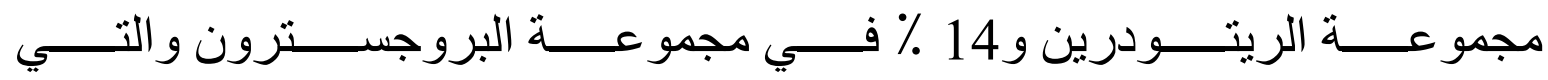
كان لها دلالة إحصائية.

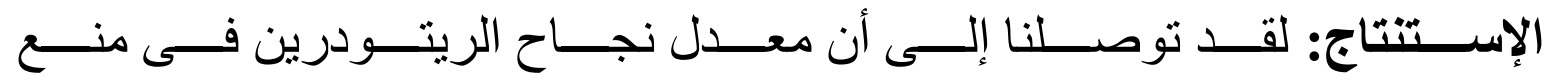

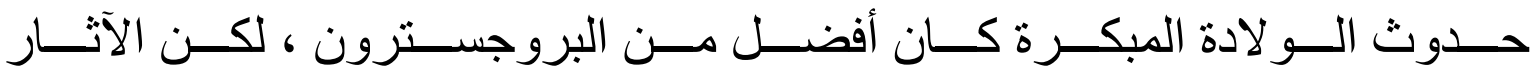

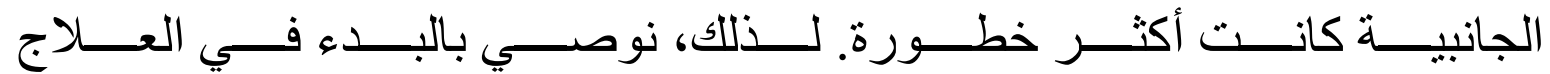

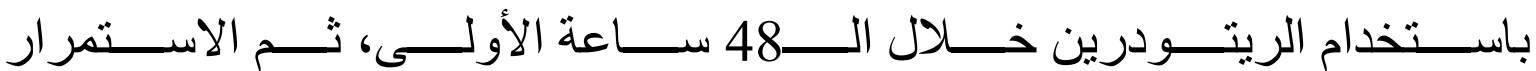

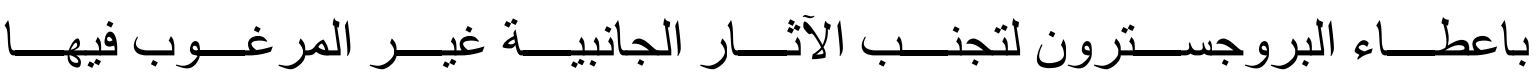
للايتودرين. 